\title{
PATIENTS WITH CORONARY ARTERY DISEASE - MAINTAINING PLANNED LIFESTYLE ADAPTATIONS
}

\section{Karien Engelbrecht}

M Cur

Registered Intensive Care Nurse

\section{Elzabé Nel}

DCur

Senior Lecturer, School of Nursing, Faculty of Health Sciences, University of Johannesburg

Corresponding author: ewnel@uj.ac.za

\section{Wanda Jacobs}

MCur

Lecturer, School of Nursing, Faculty of Health Sciences, University of Johannesburg

Keywords: lifestyle adaptations; coronary artery disease; coronary artery risk factors; guidelines for lifestyle adaptations

\begin{abstract}
The purpose of this study was to describe how patients with coronary artery disease, who have had one or more cardiac interventions, were maintaining their planned lifestyle adaptations at four months after the intervention. Furthermore, the study aimed to develop guidelines to further assist patients in maintaining lifestyle adaptations. A descriptive study was undertaken using the survey method. The population consisted of 65 participants (42 males, 23 females) from five private hospitals in Gauteng. The questions for a questionnaire were derived from a conceptual framework. The participants first completed the questionnaire immediately before they were discharged, and again over the telephone four months after the intervention. Descriptive statistics were used to analyse the data obtained. The results showed that patients suffering from coronary artery disease do adapt their lifestyle after interventions, but most patients find it problematic to stop smoking. It is essential for patients with coronary artery disease to maintain lifestyle adaptations to ensure further health and prevention of recurrence of the same problems. These adaptations should be a lifelong commitment.
\end{abstract}

\section{OPSOMMING}

Die doel van die studie was om te beskryf hoe pasiënte met koronêre vatsiektes wat een of meer kardiale prosedures ondergaan het, die beplande verandering aan hulle lewenstyl op vier maande na die prosedures handhaaf. Verder het die studie gepoog om riglyne daar te stel wat pasiënte kan help om lewenstylaanpassings vol te hou. 'n Opnamemetode is gebruik om 'n beskrywende studie uit te voer. Die populasie het uit 65 deelnemers (42 mans en 23 vroue) van vyf privaat hospitale in Gauteng bestaan. ' $n$ Vraelys is vanuit 'n konseptuele raamwerk saamgestel. Die vraelys is net voor ontslag aan die deelnemers gegee om te voltooi, en weer telefonies vier maande na ontslag. Beskrywende statistiek is gebruik om die data te ontleed. Die resultate toon dat pasiënte wat aan koronêre vatsiektes ly wel hulle lewenstyl aanpas na 'n kardiale prosedure, hoewel die meeste dit problematies vind om op te hou rook. Dit is noodsaaklik vir pasiënte met koronêre vatsiektes om hulle lewenstylaanpassing vol te hou om sodoende te verseker dat hulle gesondheid gehandhaaf word en herhaling van dieselfde probleme voorkom word. Hierdie aanpassings moet 'n lewenslange verbintenis wees. 


\section{IMPORTANCE OF STUDY}

While working in an intensive care unit and nursing patients with coronary artery disease, it came to the attention of the authors that patients who had previously had interventions are often re-admitted to hospital with the same problem. Many of these patients admit that they were informed about lifestyle adaptations and that they knew these changes were in the best interests of their health although not maintained by the patients. By researching the problem areas for maintaining lifestyle adaptations, recommendations can be made to assist patients in these problem areas.

\section{INTRODUCTION}

Coronary artery disease (CAD) is an insidious, progressive disease that results in coronary narrowing or complete occlusion. There are numerous causes of CAD, but atherosclerosis is the most prevalent. Symptoms such as angina pectoris occur only when the atherosclerotic plaque occludes $75 \%$ of the vessel lumen. The Framingham Heart Study, which commenced in 1948 and continues today with third and fourth generations as participants, identified risk factors for CAD, and more specifically for atherosclerosis (Urden, Stacey \& Lough, 2002:395). See Table 1.

CAD is the most common cardiovascular disorder in adults. It is an accepted fact that the incidence of CAD has reached endemic proportions in South Africa (Stellenberg \& Bruce, 2007:7). Coronary artery bypass graft surgery, percutaneous transluminal coronary angioplasty and the insertion of a coronary stent (hereafter collectively referred to as cardiac interventions ${ }^{1}$ ) are major therapeutic approaches to the treatment of CAD, but in themselves do nothing to correct the underlying disease process (Stellenberg \& Bruce, 2007:20). A careful CAD risk profile assessment and lifestyle adaptation of the modifiable risk factors should always accompany such dramatic and expensive interventions (Lindsay \& Gaw, 2004:9; Pell, 1997:10).

1 Although these procedures are collectively referred to as cardiac nterventions, for the purpose of this article, it should be noted that a single intervention may have been performed.

Lifestyle is defined as the values and behaviours adopted by a person in daily life, and adaptation as the process of modifying a person's lifestyle to meet new, changing or different conditions. Lifestyle adaptation thus refers to modifying and changing everyday behaviour (Kozier, Erb, Blais \& Wilkinson, 1995:144)i

Important in this study is the extent to which patients change their everyday behaviour to lead healthier lives by adapting the modifiable risk factors for CAD present in their lives after a cardiac intervention.

A patient is a holistic being and someone who is waiting for or undergoing medical treatment and care (Kozier et al., 1995:27). For the purpose of this study, a patient was regarded as someone who had undergone a cardiac intervention. The patient had also received professional guidance on how to adapt their lifestyle to ensure optimum health and to enable them to function to their maximum potential. As patients are social beings, it is important to acknowledge their families, their social structures and environment (Mason, 1987:20) when addressing their lifestyles.

Patients with CAD should firstly understand that, to maintain a healthy body, they have to make certain meaningful lifestyle adaptations. Furthermore, the process, extent and benefit of these lifestyle adaptations should be made clear to them. After their cardiac interventions, patients are often confused about how they are expected to adapt their lifestyle. This, unfortunately, can often be attributed to the fact that some cardiologists and cardiothoracic surgeons are inclined to suggest that all the patient's problems will be solved by the operation or procedure. Before the intervention, patients are often unaware that they suffer from CAD and that after surgery they should follow secondary preventive measures such as risk modification and lifestyle adaptation for the rest of their lives (Wenger, 1997:137-138).

The multidisciplinary team is a major source of information to these patients on lifestyle adaptations. All members play an equally important role to help the patient to adapt to a new lifestyle. This study, however, focuses on the functions of the nurse.

As soon as a patient is diagnosed with CAD in the hospital, adapting to a new lifestyle commences. As the primary care-giver in the hospital, it is the nurse's function to educate patients regarding their lifestyle adaptations (Clochesy, Brue, Cardin, Whittaker \& Ruby, 1996:889). 


\section{PROBLEM STATEMENT}

While working in the cardiac intensive care unit, the researchers have noticed the re-admission of numerous patients after their first cardiac intervention. After assessing these patients' health status on admission, it became evident that some had failed to make any lifestyle adaptations after their first intervention. Upon questioning these patients, it further emerged that some did make or planned to make lifestyle adaptations directly after their first intervention, although they did not adhere to the changes.

Should patients choose not to change or maintain their lifestyle, the progress of CAD may increase, and patients could then be re-admitted to hospital. The researchers pondered the question:

How many of the patients that receive cardiac intervention maintain their lifestyle adaptations?

\section{PURPOSE}

The purpose of this study was to describe how patients who underwent cardiac interventions were maintaining their planned lifestyle adaptations at four months after the interventions. This information was used to develop guidelines for nurses to assist with the maintenance of these lifestyle adaptations.

\section{CONCEPTUAL FRAMEWORK}

The aim of the conceptual framework was to derive questions for a questionnaire. The number of questions that were derived from each discussion will be given at the end of the discussion to construct a trail of evidence to increase the reliability of the questionnaire.

\section{Risk factors for coronary artery disease}

It is encouraging to know that public awareness of risk factors contributing to the development of CAD is increasing. However, as people now live longer than before and cardiovascular disease is most prevalent in elderly people, CAD continues to be a worldwide public health problem (Lindsay \& Gaw, 2004:33). Factors that increase the risk of developing $C A D$ are listed in Table 1 (Lindsay \& Gaw, 2004:33).
The modifiable risk factors (Table 1) should be addressed by patients in their lifestyle adaptations. Fourteen questions, mainly biographical, were derived from the following risk factors:

previous admission to hospital with cardiac events; gender; weight; height; family history; cholesterol high fat diet; obesity; diabetes mellitus; physical inactivity; smoking; oral contraceptives for women; hypertension; stress; and the consumption of alcohol.

\section{Lifestyle adaptations}

Some patients do not have to change their lifestyle significantly, as they already follow a healthy regime. Unfortunately, others have to make major adaptations to enable them to have a healthy lifestyle. These adaptations are listed below:

\section{Behavioural adaptation}

Patients suffering from CAD should realise the seriousness of the disease. They should understand that it is vital to adapt their lifestyle to ensure better health. This should be used as a starting point to encourage patients to embrace the concept of adaptation. These changes are in accordance with the first phase of the cardiac rehabilitation process. In this way a positive approach towards recovery, early mobilisation and discharge can be established (Hatchett \& Thomson, 2002:231).

CAD is largely dependent on the behavioural and psychological circumstances of the patient. Cigarette smoking, dietary behaviour, exercise levels and the prevalence and impact of psychological stress are considered key behavioural risks.

Although patients may ultimately wish to optimise their health, whether or not they engage in health-promoting behaviours is governed to a greater extent by shortterm costs and benefits than by long-term possible health outcomes. Patients may consider adopting a low-fat diet to reduce their risk of CAD, but be beset by more immediate problems. Their families may not wish to adapt their diet, they may have to learn new cooking methods, eat brand foods, perhaps even increase the cost of their shopping. These short-term costs may override the benefit of potential long-term health gains and prevent adoption of appropriate behavioural change (Lindsay \& Gaw, 2004:217-234). 
Table 1: Factors increasing the risk of developing CAD

\begin{tabular}{|l|l|}
\hline Non-modifiable risk factor & Modifiable risk factor \\
\hline Age & Elevated serum lipids \\
\hline Gender & High fat diet \\
\hline Family history & Obesity \\
\hline & Diabetes mellitus \\
\hline & Physical inactivity \\
\hline & Homocystein \\
\hline & Smoking \\
\hline & Oral contraceptives \\
\hline & Hypertension \\
\hline & Stress and anger \\
\hline & Alcohol \\
\hline
\end{tabular}

(Lindsay \& Gaw, 2004:33)

Table 2: Body mass index

\begin{tabular}{|l|l|l|}
\hline Body mass index & Classification & $\begin{array}{l}\text { Risk of developing } \\
\text { CAD }\end{array}$ \\
\hline$<18.5$ & Underweight & Low \\
\hline $18.5-24.9$ & Normal & Low \\
\hline $25.0-29.9$ & Overweight & Increased \\
\hline $30.0-34.9$ & Obese & High \\
\hline $35.0-39.9$ & Very obese & Very high \\
\hline$>40$ & Extremely obese & Extremely high \\
\hline
\end{tabular}

(Kozier, Erb, Berman \& Snyder, 2004:1175)

Eight questions with the following themes regarding behavioural adaptation were included in the questionnaire: Patients' thoughts about the seriousness of their illness; their intention to adapt their lifestyle; their intention to change their lifestyle; and support shown by their family.

\section{A healthy diet to maintain a healthy weight} Hyperlipidaemia, obesity, diabetes, alcohol and hypertension are recognised as major risk factors for CAD. Dietary modifications play an important role in the management of these risk factors. If a patient's diet consists of excessive amounts of food, especially foods high in saturated fat, sugar, alcohol and salt, it could cause hyperlipidaemia, hypertension, diabetes mellitus and obesity. (Obesity is measured according to the body mass index see Table 2). It is not uncommon for individuals to present with one or more of these conditions (www.medicineNet.com, n.d.). These conditions are mainly responsible for the development of atherosclerosis with the consequences of coronary artery heart disease. In the questionnaire, five questions were on eating a healthy diet and maintaining a healthy weight.

To achieve and maintain a heart-healthy eating pattern, the following guidelines are recommended (www.medicineNet.com, n.d.): Eat five or more servings of a variety of fruit and vegetables per day. Eat a variety of grains, choosing six or more servings. Include 
low-fat dairy products, fish (at least two servings per week), legumes, poultry (skin removed) and lean meats. Balance the total number of calories consumed with the total energy used each day to maintain a healthy body weight. Limit alcohol intake to no more than one alcoholic drink per day for women and no more than two drinks per day for men.

A total of eight questions were derived from this section for the questionnaire. These questions were aimed at obtaining information regarding the following:

- obesity;

- the amount of red meat, fish, grains, vegetables and fruit eaten per week;

- the amount of alcohol intake; and

- $\quad$ importance of changing to a healthy diet.

\section{Smoking}

Smoking is the main avoidable cause of premature death and ill health in the world. The main diseases caused by smoking are CAD and lung cancer. The more cigarettes smoked per day, the greater the risk of CAD. Cigarette smoking alters serum lipid levels unfavourably and decreases HDL cholesterol (good cholesterol) levels. Smoking rapidly increases the heart rate and constricts blood vessels, while simultaneously reducing the blood's capacity to carry oxygen. It is associated with both aspects of atherosclerosis. It promotes the development of atherosclerosis lesions, thus creating sites susceptible to blockage, and further promotes the occurrence of triggering events, such as the adhesion of platelets to these lesions, which lead to blockage of arteries (Lindsay \& Gaw, 2004:135; Urden, Stacey \& Lough, 2002:397).

There are considerable long-term benefits for the cardiovascular system if the patient stops smoking and these benefits apply to all age groups and all stages of cardiovascular disease. The excess risk of CAD as a result of smoking reduces by half within one year of stopping the habit. After 15 years, the risk reverts to about the same level as that of someone who has never smoked. As would be expected, the level to which the risk drops varies between individuals and depends on how long the patient smoked, how heavily they smoked and other risk factors present. For an individual who already has heart disease or who has had a heart attack, giving up smoking reduces the risk of premature death or another heart attack by up to $50 \%$ or more
(Lindsay \& Gaw, 2004:134-135).

Usually patients hold health professionals in high esteem and the latter are thus in a position to provide/ suggest an intervention to assist smokers to stop. The most effective intervention strategy is minimal intervention, backed up by referral to specialist services. Minimal intervention aims to equip patients with knowledge and to motivate them to adopt different behaviour (www.medicineNet.com, n.d.).

Four questions regarding smoking habits were included in the questionnaire:

- Does the patient smoke?

- How many cigarettes does the patient smoke per day?

- Has the patient attempted to stop smoking before?

- $\quad$ Does the patient understand the complications of smoking?

\section{Exercise}

Physical activity is key to improving health and wellbeing. The British Heart Foundation has calculated that $37 \%$ of deaths from CAD of people under the age of 75 are attributable to physical inactivity. Exercise has not only physical but also emotional benefits and is an excellent component of stress management. The benefits of regular physical activities include lowering cholesterol (hyperlipidaemia), weight reduction and decreasing hypertension - all major risk factors of CAD. The idea behind exercise is that a regular training programme will improve general cardiovascular fitness. A person should participate in at least 30 minutes of physical activity on most days (www.medicineNet.com, n.d.). Two questions were included in the questionnaire regarding physical activities: Which of the following reflects the current exercise level of the patient and where does the patient exercise? What goal does the patient aim to achieve with increased activity?

\section{RESEARCH DESIGN}

A descriptive design was chosen (Burns \& Grove, 2001:248-250), as a true experimental design would have resulted in the control group not receiving education regarding lifestyle adaptations. This was considered to be unethical. 


\section{RESEARCH METHODOLOGY}

\section{Population and sampling}

A population refers to a specific set of organisations/ individuals with particular characteristics used in a study (De Vos, 1998:198). The target hospitals were all hospitals that perform cardiac interventions. Purposive sampling was done of these hospitals.

The target participants were those on whom cardiac interventions had been performed. A purposive sample was drawn (Burns \& Grove, 2001:298), based on the following predetermined sample selection criteria from the purposive sampled hospitals:

- $\quad$ diagnosed with CAD and underwent cardiac interventions;

- uncomplicated chain of events during their hospital stay (no longer than 14 days in hospital for coronary artery bypass graft and no longer than 7 days for percutaneous transluminal coronary angioplasty and insertion of a coronary stent);

- $\quad$ understood and spoke English or Afrikaans; and

- $\quad$ could be contacted by telephone.

\section{ETHICAL CONSIDERATIONS}

All ethical considerations, including autonomy, privacy, beneficence and freedom from harm, were taken into account according to the University of Johannesburg's ethical standards (clearance reference number: 43/05).

\section{MEASURES TO ENSURE VALIDITY AND RELIABILITY}

\section{Content validity of the questionnaire}

Questions for the questionnaire were derived from a conceptual framework of the study (see framework). Senior staff in the cardiac intensive care unit and rehabilitation nurses were given questionnaires to validate the content.

\section{DATA COLLECTION}

A survey using a questionnaire was used to collect the data. Refer to the conceptual framework for the con- tent of the questions posed in the questionnaire.

\section{Permission}

Permission was obtained from the participating hospital and also from the participants by means of a permission letter and consent letter which they had to sign.

\section{Data collectors}

Owing to the physical location of some of the hospitals and to the fact that the researchers could not always be in a particular hospital immediately before a patient was discharged, the researchers were forced to use data collectors to distribute the questionnaire, which patients had to complete before they were discharged. The data collectors were trained by one of the researchers in identifying the target population, to explain the research and to obtain consent. They also assisted the participants in completing the questionnaire and collected the completed questionnaires to hand back to the researchers. This ensured that all participants were treated in the same manner.

\section{Data collection instruments}

The questionnaire included open-ended, closed and multiple-choice questions. It consisted of 36 questions as reflected in the conceptual framework. The questionnaires were completed in approximately 30 minutes.

\section{Data collection process}

The process of completing the questionnaires immediately before discharge took place over a period of five months (from September 2005 to January 2006) to ensure as many participants as possible.

The prospective participants were approached by one of the researchers or fieldworkers while still in hospital. Written, signed and informed consent was obtained from the patients. By signing the consent, participants agreed to complete a questionnaire before discharge and again at four months after the cardiac intervention. Even though the participants' names and telephone numbers were obtained with the questionnaire, it was explained, and the participants understood, that their telephone numbers were only for administrative purposes and would not be used in publication of the study. After four months a researcher phoned the participants and the 
questionnaire was completed over the telephone for the second time.

\section{PILOT STUDY}

A pilot study in which two patients participated was carried out to determine the feasibility of the study and the reliability and validity of the questionnaires. After completion of the pilot study, only minor changes were made to the questionnaire. The introductory note was changed to convey a friendlier and conversational tone, making it easier for the participant to read and understand.

\section{RESULTS}

Five private hospitals in the west and central Gauteng participated in the study, and included 65 patients $(\mathrm{N}=65)$.

Of the 65 participants, 42 were male (64.6\%) and 23 female (35.4\%). The participants' ages ranged between 30 and 80 years with a mean of 58 years and median of 59 years. According to South African statistics, CAD is the seventh cause of natural deaths among South Africans in the age group 50-64 years, the age group that correlates with this study.

The risk factors of the participants for developing CAD are shown in Table 3. In this table $\mathrm{N}=69$, but it should be considered that one participant could have more than one risk factor. Among the participants, hypertension was indicated as the most prevalent risk factor. Another risk factor was the mean $\mathrm{BMI}$ of 27 , indicating that as a group the participants were overweight. According to Table 2, this indicates an increased risk of developing CAD. According to Urden et al. (2002:397), obesity is the second largest leading cause of CAD.

\section{Lifestyle adaptation}

The attitudes of the participants towards lifestyle changes before discharge were positive. Fifty-five (84.6\%) participants felt that lifestyle changes were extremely important, seven (10.8\%) thought that they were very important and three (4.65\%) thought that they were not important (see Table 4).

Although 62 participants stated before discharge that it was important to change their lifestyles, only 60 (96.7\%) had in fact changed their lifestyles after four months.

\section{Activity levels}

Table 5 shows the activity levels of the participants at four months, where more participants became active than before discharge. Regular activity and exercise can reduce the risk of cardiac events.

\section{Consumption of fish and poultry}

It is advisable for patients to eat more fish and poultry, especially when suffering from CAD. According to hearthealthy eating (www.medicineNet.com, n.d.), at least two protein servings per week should be fish, and two should be skinless chicken. Table 6 illustrates how the participants changed their lifestyle to consume more fish. This table is divided into three groups. Group 1 consists of the participants who never ate fish or poultry, or maybe only once a week. Group 2 consists of the participants who ate fish or poultry 2-3 times per week, and group 3 consists of the participants who ate fish or poultry 5-6 times per week.

In group 1 the 19 (29.2\%) participants who stated before discharge that they never ate fish or ate fish and poultry once a week indicated at four months that they had changed their eating habits to $6(9.2 \%)$ who ate fish and poultry 2-3 times a week and 8 (12.3\%) who ate fish and poultry 5-6 times a week.

Of the 34 (52.3\%) participants in group 2 who indicated before discharge that they ate fish and poultry 2-3 times a week, at four months 10 (15.4\%) participants continued to eat fish and poultry 2-3 times a week while 24 (36.9\%) participants changed to eating fish and poultry 5-6 times a week.

Twelve (18.5\%) participants indicated that they ate fish or poultry 5-6 times per week before the interventions and at four months 3 (4.6\%) participants decreased their fish and poultry servings to only 2-3 times a week.

\section{Consumption of fruit, salads or vegetables}

Table 7 shows the consumption of salads and vegetables. It would appear that at four months most of the 
Table 3: Risk factors of the participants

\begin{tabular}{|l|l|l|}
\hline Risk factors & Frequency & Percentage \\
\hline Hypertension & 28 & $40.6 \%$ \\
\hline Diabetes & 10 & $14.5 \%$ \\
\hline Genetic predisposition & 14 & $20.3 \%$ \\
\hline Nothing & 17 & $24.6 \%$ \\
\hline Total & $\mathrm{N}=69$ & $100 \%$ \\
\hline
\end{tabular}

Table 4: Attitudes towards lifestyle adaptations and number of participants who made lifestyle adaptations

\begin{tabular}{|l|l|l|l|l|l|}
\hline \multicolumn{4}{|l|}{ Attitude before discharge } & \multicolumn{2}{l|}{ Made adaptations } \\
\hline Response & Not important & Important & Very important & No change & Change \\
\hline Participants N=65 & $3(4.65 \%)$ & $7(10.8 \%)$ & $55(84.6 \%)$ & $5(3.2 \%)$ & $60(96.8 \%)$ \\
\hline
\end{tabular}

Table 5: Activity level

\begin{tabular}{|l|l|l|}
\hline & \multicolumn{2}{|l|}{ 4 months } \\
\hline Response & Less active & More active \\
\hline $\begin{array}{l}\text { Participants } \\
\mathrm{N}=65\end{array}$ & $13(20 \%)$ & $52(80 \%)$ \\
\hline
\end{tabular}

Table 6: Consumption of fish and poultry

\begin{tabular}{|l|l|l|}
\hline Fish and poultry & Before discharge & At four months \\
\hline Group 1 & & \\
\hline Never or once a week & 19 & 5 \\
\hline 2-3 times a week & & 6 \\
\hline 5-6 times a week & & 8 \\
\hline Group 2 & & \\
\hline 2-3 times a week & 34 & 10 \\
\hline 5-6 times a week & & 24 \\
\hline Group 3 & & \\
\hline 5-6 times a week & 12 & 9 \\
\hline 2-3 times a week & & 3 \\
\hline Total & 65 & 65 \\
\hline
\end{tabular}


participants had increased their salad or vegetable consumption to 5-6 times per week, or at least continued to eat salads or vegetables about 5-6 times per week.

The consumption of fruit per week showed a similar trend, namely that the participants started to eat more fruit and were maintaining this eating pattern at four months.

\section{Consumption of alcohol}

At four months, of the 24 (36.9\%) participants who indicated that they never consumed alcohol, 2 (3\%) started consuming 1-4 glasses of alcohol per week. Of the 35 (53.9\%) participants who stated that they consumed 1-4 glasses of alcohol per week, 1 (1.5\%) started consuming 5 or more glasses of alcohol and 1 (1.5\%) stopped using alcohol altogether.
Various studies have shown that the moderate intake of alcohol (one drink per day) significantly improves the elasticity of arteries, which is an important indicator of cardiovascular health. This positive effect seems to be true not only of red wine, but even of beer and hard liquor. Conversely, studies have proved that heavy drinking is detrimental to cardiovascular health (www.heartcentreonline.com, n.d.; Lindsay \& Gaw, 2004:163-164).

\section{Body mass index}

The effect of this healthier eating style was demonstrated in the BMI. Paired sample statistics were used to compare the mean BMI of the participants, which was 27.17 before the interventions, and had decreased to 26.09 at four months. Although the results remained in the classification of overweight, there was a decrease in weight, indicating that the participants were main-

Table 7: Consumption of salads

\begin{tabular}{|l|l|l|}
\hline Salads & Before discharge & 4 months \\
\hline Group 1 & & \\
\hline Never or once a week & 12 & 1 \\
\hline 2-3 times per week & & 1 \\
\hline 5-6 times per week & & 10 \\
\hline Group 2 & & \\
\hline 2-3 per week & 24 & 3 \\
\hline 5-6 times per week & & 21 \\
\hline Group 3 & & \\
\hline 5-6 times per week & 29 & 28 \\
\hline 2-3 times per week & & 1 \\
\hline Total & 65 & 65 \\
\hline
\end{tabular}

Table 8: Smoking habits

\begin{tabular}{|l|l|l|l|}
\hline & $\begin{array}{l}\text { Before } \\
\text { intervention }\end{array}$ & 4 months \\
\hline Response & & $\begin{array}{l}\text { Continued/ } \\
\text { started }\end{array}$ & $\begin{array}{l}\text { Stopped } \\
\text { smoking }\end{array}$ \\
\hline $\begin{array}{l}\text { Participants } \\
\mathrm{N}=40\end{array}$ & 40 & $19(47.5 \%)$ & $21(52.5 \%)$ \\
\hline
\end{tabular}


taining their lifestyle adaptation.

\section{Smoking}

The participants found it much harder to stop smoking than doing exercise and eating more healthily. Urden et al. (2006:542) propose that all smokers should receive educational counselling and be offered smoking cessation therapy, as it is difficult for smokers to stop smoking. As smoking increases the risk of premature death or another heart attack by up to $50 \%$ or more (Lindsay \& Gaw, 2004:134-135), this result is alarming. Table 8 shows the results of the participants' smoking habits.

Before being discharged, all 40 participants stated that they would stop smoking. At four months, of the 40 (61.5\%) participants who stated that they smoked before the intervention, 21 (32.3\%) had not started smoking again, but 19 (29.2\%) had.

\section{CONCLUSION}

It seems that most of the participants did adapt and maintain their lifestyle after their cardiac intervention. Sixty participants (96.7\%) had in fact changed their lifestyles after four months, for example more participants became active than before discharge, participants started eating more fruit and maintained this eating pattern and there was a decrease in weight. However, participants decreased their fish and poultry servings to only 2-3 times a week. Stopping smoking proved to be the most problematic adaptation, because 19 participants (29.2\%) started smoking again.

\section{GUIDELINES}

The following guidelines are formulated to help patients with CAD, not only to adapt their lifestyles and follow a healthier way of living, but also to assist them in maintaining this new, healthy lifestyle. Conclusions were drawn based on the data gathered from questionnaires.

\section{Attitude towards lifestyle adaptations}

To ensure successful lifestyle adaptations, patients need to show a positive attitude. This would require:

- education on the seriousness of CAD;

- ensuring that patients understand the impor- tance of adapting their lifestyle and that these changes would ensure better health; and

- ensuring that the families are positive about and involved in the lifestyle adaptations.

\section{Diet and alcohol}

- Where alcohol is concerned, patients should be encouraged to drink moderate amounts (14 glasses per week) of alcohol.

- Red meat consumption should decrease. Patients should be guided in terms of healthier substitutes for red meat and healthier options in preparing red meat.

- The consumption of fish and chicken (skin removed) should be increased to at least two servings per week.

- The consumption of salads, vegetables and fruit should increase to five or more servings daily.

- Cholesterol-raising fats such as saturated fats should be limited to $300 \mathrm{mg}$ per day.

- The intake of foods with high calorie content should be limited.

\section{Smoking}

Patients should be:

- educated on the side-effects of smoking;

- continuously motivated to stop smoking;

- encouraged to adopt a new lifestyle, but one stage at a time; and

- referred to specialist services to assist them to stop smoking.

\section{Activity levels}

- Patients need to maintain a level of physical activity that keeps them fit and matches the calorie intake to maintain a healthy body weight.

- They should participate in at least 30 minutes of physical activity on most days.

\section{LIMITATIONS}

The study was conducted over a short period. As lifestyle adaptation is a lifelong adjustment, the limited time span may not reflect the lifelong adjustments made by patients, and it is therefore recommended that fu- 
ture studies of this kind be conducted over a longer follow-up period.

\section{RECOMMENDATIONS}

\section{Recommendations for nursing education}

In the basic education of nurses, students should be taught about patient education regarding lifestyle adaptation, support and counselling, as it encompasses many areas of nursing.

Guidelines should be formulated for patients to assist and support them in adapting their lifestyles. The effectiveness of these guidelines should be monitored over an extended period.

\section{Recommendations for further nursing re- search}

The study was conducted covering a short period of 4 months. It is recommended that it be run for a much longer interval period to effectively measure the lifestyle adaptations of patients with CAD over longer time.

\section{Recommendations for nursing adminis- tration}

The guidelines for lifestyle adaptation of the patient should be operationalised and implemented in nursing practice.

Nurses working in a coronary unit should also have continuous education on lifestyle adaptation and relevant community resources. This can be done by means of formal lectures, visits to community resource centres and through their own research projects.

\section{REFERENCES}

BURNS, N \& GROVE, SK 2001: The practice of nursing research: Conduct, critique and utilization; $4^{\text {th }}$ edition. Philadelphia: WB Saunders.

CLOCHESY, JM; BRUE, C; CARDIN, S; WHITTAKER, AA\& RUBY, EB 1996: Critical care nursing; $2^{\text {nd }}$ edition. Philadelphia: WB Saunders.

DE VOS, AS (ed.) 1998: Research at grass roots: A primer for the caring professions. Pretoria: Van Schaik.

HATCHETT, R \& THOMPSON, D 2002: Cardiac nursing. A compre- hensive guide. London: Harcourt. HEARTCENTREONLINE FOR CARDIOLOGISTS AND THEIR PA-

TIENTS 2004: Coronary artery bypass surgery. www heartcenteronline.com (Accessed 2 September 2004).

KOZIER, B; ERB, G; BLAIS, K \& WILKINSON, JM 1995: Fundamentals of nursing. Concepts, process and practice; $5^{\text {th }}$ edition. California: Addison-Wesley.

KOZIER, B; ERB, G; BERMANA \& SNYDERS,SJ 2004: Fundamentals of nursing. Concepts, process and practice; $7^{\text {th }}$ edition. California: Addison-Wesley

LINDSAY, G \& GAW, A 2004: Coronary heart disease prevention: A handbook for the health-care team; $2^{\text {nd }}$ edition. Philadelphia: Churchill Livingstone.

MASON, CB 1987: Cardiovascular critical care. New York: Van Nostrand Reinhold.

MEDICINENET.COM. n.d.: Coronary artery bypass graft surgery. http://medicinenet.com (Accessed 3 October 2004).

PELL, J 1997: Cardiac rehabilitation: A review of its effectiveness. Coronary Health Care, 1:8-17.

URDEN, LD; STACEY, KM \& LOUGH, ME 2002: Thelan's critical care nursing: Diagnosis and management; $4^{\text {th }}$ edition. Missouri: Mosby.

URDEN, LD, STACEY, KM \& LOUGH, ME 2006: Thelan's critical care nursing: Diagnosis and management; $5^{\text {th }}$ edition. Missouri: Mosby.

STELLENBERG, EL \& BRUCE, JC 2007: Nursing Practice: MedicalSurgical Nursing for Hospital and Community. Edinburgh: Elsevier. WENGER, NK 1997: Cardiac rehabilitation: Implication of the AHCPR guideline. Hospital Medicine, 33(40):31-38. 